\title{
Diagnozowanie dziecka/ucznia z mutyzmem wybiórczym
}

Diagnosing Children/Pupils with Selective Mutism

Słowa kluczowe: mutyzm, mutyzm wybiórczy, diagnoza, etapy diagnozowania

Keywords: mutism, selective mutism, diagnosis, stages of diagnosis

\section{Wprowadzenie}

W ciągu ostatnich kilku lat obserwujemy wśród logopedów, psychologów, pedagogów i nauczycieli zainteresowanie zaburzeniem określanym mianem mutyzmu wybiórczego (MW). Nowe postrzeganie niemówienia na tle lękowym, pozbawione mitów, które wokół niego narosły, pozwala specjalistom na wczesną diagnozę tego zaburzenia i jak najszybsze podjęcie działań terapeutycznych.

Pojęcie diagnoza używane jest w literaturze w dwu znaczeniach [Bogdanowicz, 1985, s. 47]:

- dla oznaczenia procesu diagnozowania, a więc poznawania osoby badanej/ przedmiotu i problemów z nimi związanych oraz

- jako skutek tego procesu, czyli podsumowanie materiału pozyskanego w przebiegu badania diagnostycznego $\mathrm{w}$ formie ustnej lub pisemnej.

Celem artykułu jest omówienie mutyzmu wybiórczego i diagnozy jako procesu oraz przedstawienie własnej propozycji klasyfikacji jego etapów.

\footnotetext{
* Uniwersytet Łódzki, Wydział Filologiczny, Zakład Dialektologii Polskiej i Logopedii, ul. Pomorska 171/173, 90-236 Łódź, e-mail: renata.marciniak@uni.lodz.pl, ORCID: https://orcid.org/0000-00 01-6301-8820.
} 


\section{Mutyzm wybiórczy - definicja, epidemiologia, wybrane dane dotyczące zaburzenia}

Mutyzm wybiórczy, inaczej selektywny, to zaburzenie lękowe, które charakteryzuje się wyraźną, zdeterminowaną emocjonalnie wybiórczością werbalnego komunikowania się, polegającą na tym, że dziecko w pewnych sytuacjach rozmawia swobodnie, ale w innych (określonych) przestaje mówić. Zaburzeniu towarzyszą zwykle pewne cechy osobowości, takie jak lękliwość, wycofywanie się, nadmierna wrażliwość lub upór (za ICD-10).

Mutyzm wybiórczy pojawia się u dzieci o wrażliwym usposobieniu, zwykle gdy wychodzą one poza krąg najbliższej rodziny, czyli w wieku 3-5 lat. Czasami zaczyna się też u starszych dzieci. Nieleczony mutyzm może przetrwać do wieku dorosłego. $\mathrm{Z}$ badań wynika, że zaburzenie dotyka od sześciu do ośmiu dzieci na tysiąc (według "Journal of the American Academy of Child and Adolescent Psychiatry" z 2002 roku siedmioro dzieci na tysiąc, czyli jedno na 140) - dwa razy częściej niż autyzm [Andrzejewska, 2015; Ołdakowska-Żyłka, Małachowska, 2015]. Maria i Ewelina Bystrzanowskie szacują, że w Polsce mutyzm wybiórczy dotyczy około 40 tys. dzieci i młodzieży w wieku 3-12 lat [Bystrzanowska, Bystrzanowska, 2019, s. 23]. Według niektórych źródeł jest on częstszy u dziewczynek niż u chłopców (2,6: 1 lub od 1,5: 1 do 2,1: 1 [Kristensen, 2002, za Ołdakowska-Żyłka, 2015, s. 61]), według innych zaburzenie występuje równie często u dziewczynek i u chłopców [Johnson, Wintgens, 2018, s. 554]. Dzieci z mutyzmem wybiórczym są bardziej narażone na inne trudności w rozwoju mowy i języka. Jak wynika z danych Steinhausena z 1996 roku, 30,3\% dzieci z mutyzmem ma zaburzenia rozwoju mowy, 38\% zaburzenia rozwoju językowego: ekspresji mowy, artykulacji [Ołdakowska-Żyłka, Małachowska, 2015]. Bardziej narażone na rozwój mutyzmu wybiórczego są dzieci dwujęzyczne oraz pochodzące $\mathrm{z}$ rodzin imigranckich, co należy wiązać $\mathrm{z}$ trudnością funkcjonowania $\mathrm{w}$ dwu systemach językowych z jednej strony, a perfekcjonizmem tych dzieci z drugiej. Dzieci z mutyzmem wybiórczym częściej pochodzą z rodzin, w których inne osoby także są nieśmiałe, odczuwają lęk lub mają trudności w kontaktach społecznych. Zaburzenie może trwać od kilku miesięcy do kilku lat, a jego utrzymywanie się powyżej 10. roku życia źle prognozuje [Skoczek, 2015, s. 27; Johnson, Wintgens, 2018, s. 554-555].

\section{Przyczyny mutyzmu wybiórczego}

Przyjmuje się, że mutyzm to zespół heterogenny, czyli w etiologii tego zaburzenia istotne jest współwystępowanie i oddziaływanie na siebie kilku czynników [Urbaniuk, 2008, s. 456].

Maggie Johnson i Alison Wintgens [2018, s. 23] wymieniają trzy elementy, które składają się na proces „warunkowania lęku”, czyli przyczyny MW. Są to: 
- wrażliwa osobowość - kombinacja czynników genetycznych (dziedzicznych) i psychologicznych czyni pewne jednostki szczególnie podatnymi na powstanie zaburzeń lękowych;

- wydarzenia życiowe - sprzyjają wytworzeniu skojarzenia między potrzebą mówienia a silnym lękiem;

- zachowania podtrzymujące - reakcje innych osób wzmacniają dziecięce przekonanie, że mówienie jest trudne, stresujące i najlepiej go unikać.

Z reaktywną osobowością dziecka, powodującą jego wrażliwość, nieufność i niepokój, często idą w parze:

- nieśmiałość, mutyzm wybiórczy, zaburzenia lękowe lub inne zaburzenia psychiczne, które przechodzą w rodzinie z pokolenia na pokolenie;

- trudności w zakresie mowy lub języka;

- lęk separacyjny;

- perfekcjonizm;

- martwienie się;

- negatywizm.

Nierzadko pojawiają się również problemy z integracją sensoryczną i nadmierną stymulacją oraz opóźnienie rozwoju ruchowego [Jonson, Wintgens, 2018, s. 60]. Poczuciu zagubienia, braku pewności siebie lub strachu przed popełnieniem błędów sprzyjają między innymi: brak konsekwencji w wychowaniu, rzadkie okazje do rozwiązywania problemów i radzenia sobie z trudnościami, brak wyznaczonych granic, zbyt duża odpowiedzialność nakładana na dziecko, krytyka lub brak pochwał, wygórowane standardy/oczekiwania wobec dziecka [Jonson, Wintgens, 2018, s. 60]. Do wydarzeń życiowych, które wywołują stres i sprzyjają wytworzeniu skojarzenia między potrzebą mówienia a silnym lękiem, należą między innymi: separacja od rodziców, nieznane, głośne i ruchliwe otoczenie, trudności z mówieniem lub byciem zrozumianym, presja osiągnięć, dokuczanie lub zastraszanie, przedrzeźnianie mowy dziecka, rozwód rodziców, pojawienie się rodzeństwa, kłótnie rodziców, przeprowadzka, emigracja, choroba w rodzinie, pobyt w szpitalu, branie udziału lub bycie świadkiem katastrofy czy klęski żywiołowej (powódź, pożar, wypadek drogowy), śmierć, strata członka rodziny, przyjaciela lub ulubionego zwierzęcia, szok po pogryzieniu przez psa. W przypadku zachowań podtrzymujących do wzmacniających stres u dziecka reakcji innych osób należą: presja mówienia, dezaprobata/kary, usuwanie potrzeby mówienia, lęk rodziców, większa dawka uwagi i pocieszenia, gdy pojawia się lęk przed mówieniem, przypisanie „roli” milczącego dziecka, brak potrzeby zmiany czy oczekiwanie zmiany bez właściwego zrozumienia zaburzenia i interwencji [Radomska, Jankowska, 2000, s. 20-21; Urbaniuk, 2008, s. 457; Johnson, Wintgens, 2018, s. 60]. Poza wymienionymi sytuacjami oraz postawami lęk i wrażliwość dziecka mogą zwiększać także inne okoliczności, na przykład: świadomość własnej wady wymowy lub innych trudności, negatywne postawy wobec komunikacji i rozwiązywania problemów w rodzinie, nadmierne ostrzeganie przed rozmawianiem 
z obcymi lub podejmowaniem ryzyka, izolacja geograficzna lub społeczna (rodzice opisują swoje rodziny jako odseparowane od dalszej rodziny, przyjaciół, znajomych; rodzina należąca do mniejszości etnicznej lub językowej), historia rodzinna nieśmiałości, mutyzmu wybiórczego czy innego zaburzenia mowy lub języka (rodzice też mogą być wycofani, zamknięci, często mówią o sobie, że też mają mutyzm; nierzadko rodzice sami nie „odcięli pępowiny” od swoich rodziców), historia rodzinna chorób psychicznych (często w rodzinie dziecka z mutyzmem są osoby ze schizofrenią), dojrzewanie płciowe.

\section{Objawy mutyzmu wybiórczego, obraz dziecka/ucznia z mutyzmem wybiórczym}

Prawidłowe zdiagnozowanie mutyzmu wybiórczego wymaga przede wszystkim znajomości objawów tego zaburzenia oraz portretu psychologicznego dziecka/ucznia z MW. I tak mutyzm wybiórczy objawia się [Janik, 2012, s. 81; Warchał, Warchał, 2012, s. 99; Skoczek, 2015, s. 35-37; Bystrzanowska, 2017, s. 22-23; Johnson, Wintgens, 2018, s. 19]:

- silnym lękiem społecznym;

- dużą wrażliwością i uporem;

- nadmiernym kontrolowaniem otoczenia;

- wycofywaniem się, zamknięciem w sobie, brakiem swobody w zachowaniu, niską samooceną;

- występowaniem zachowań agresywnych, opozycyjno-buntowniczych (szczególnie w domu);

- unikaniem kontaktu wzrokowego;

- ograniczeniem mimiki (animia), czasem tikami, przygryzaniem warg, wkładaniem palców do buzi, przygryzaniem rękawów lub kołnierzyków;

- wzmożonym napięciem mięśniowym, które zaburza możliwość wskazywania dłonią, manipulowania przedmiotami, chodzenia czy biegania; nieporadnością, sztywnością ruchów;

- trudnościami w wyrażaniu emocji;

- nadwrażliwością na hałas, dotyk, tłum, czasem smak;

- trudnościami z jedzeniem - mogą one dotyczyć miejsca spożywanych posiłków lub konsystencji pokarmów i smaków;

- trudnościami związanymi z korzystaniem z toalety publicznej, przedszkolnej, szkolnej;

- niechęcią do zmian (np. ubrania, porządku dnia); dążeniem do powtarzalności;

- izolacją społeczną (dziecko bawi się tylko z wybranymi dziećmi, ma ograniczone relacje z grupą rówieśniczą);

- patologicznym uzależnieniem się od rodzica; 
- symptomami fizjologicznymi (np. krótki, przyspieszony oddech, bladość lub czerwienienie się, omdlenia, koszmary nocne, częste moczenia się).

Mutyzm wybiórczy zazwyczaj ujawnia się u dzieci w wieku przedszkolnym. Z jednej strony dzieci te charakteryzuje wiele cech pozwalających „wyłapać je” w grupie rówieśniczej, na przykład pusty wyraz twarzy, brak uśmiechu, „zamrożony” wzrok, płytka ekspresyjność, sztywne ruchy ciała. Poza milczeniem dzieci z MW unikają kontaktu wzrokowego, kierując spojrzenie w dół lub bok, trzymają głowę i ramiona lekko przygięte do przodu przy wyprostowanym kręgosłupie, mają wahania nastroju (zwłaszcza w domu - hałaśliwość, wybuchy złości i płaczu). Cechują je podwyższona wrażliwość na otoczenie (zaburzenia integracji sensorycznej), problemy z zaangażowaniem społecznym (trudności z powitaniem, pożegnaniem, zainicjowaniem relacji, na początku spotkania $\mathrm{z}$ komunikacją niewerbalną), perfekcjonizm. $\mathrm{Z}$ zaburzeniami napięcia i niepokojem, lękiem wiążą się problemy z jedzeniem, piciem, korzystaniem z łazienki w przedszkolu/szkole, objawy somatyczne (najczęściej żołądkowe oraz związane $z$ drogami moczowymi), zachowania wynikające $z$ napięcia: moczenie, obgryzanie paznokci, agresja. Natomiast z drugiej strony dzieci z mutyzmem „na pierwszy rzut oka” wydają się zwykłymi dziećmi, są spokojne, nie sprawiają kłopotów pedagogicznych, reagują na polecenia, lubią się bawić, nie mają większych problemów z nauką, mają dobre oceny z prac pisemnych. To sprawia, że są to często dzieci „umykające” uwadze wychowawcy, nauczyciela [Andrzejewska, 2015; Ołdakowska-Żyłka, Małachowska, 2015].

Dzieci z MW opisuje się niekiedy jako zagniewane, nadąsane czy ponure, na których twarzach gości ironiczny uśmiech [Johnson, Wintgens, 2018, s. 25]. Takie opinie są dla nich krzywdzące.

Starsze dzieci i nastolatki z mutyzmem wybiórczym przejawiają strach o przyszłość, obawę przed dorosłością, wykazują ograniczoną samodzielność i niezależność (niewspółmierną do wieku), odkładają sprawy na później oraz unikają wyzwań i nowości. Cechuje je skłonność do wybierania samotnych zajęć, mają trudności z pracą w grupach, mogą być nieasertywne lub pasywne, a z drugiej strony bardzo kontrolujące, kiedy martwią się, że grupa pracuje nierówno. Mogą być smutne, odsunięte, samotne lub zbuntowane, mogą ściągać na siebie „negatywną uwagę”, aby zostać zauważone przez innych. Młodzież z mutyzmem wybiórczym ma problemy z pisaniem tekstów i testów z ograniczeniem czasowym. Uczniowie mogą czuć obawę z powodu presji związanej z nieukończeniem zadania na czas, mogą panikować, być zbyt przestraszeni, by sprawdzić swoje odpowiedzi, pisać nieczytelnym, drobnym drukiem odpowiedzi, których nie są pewni. Nieleczony niepokój może prowadzić do słabych wyników w nauce, wagarów lub porzucenia szkoły [Ołdakowska-Żyłka, Małachowska, 2015]. 


\section{Diagnozowanie dziecka/ucznia z mutyzmem wybiórczym}

W obecnie obowiązującej Międzynarodowej Klasyfikacji Chorób i Problemów Zdrowotnych ICD-10 (World Health Organization 2008) mutyzm wybiórczy został scharakteryzowany za pomocą następujących kryteriów diagnostycznych [za Ołdakowska-Żyłka, Grąbczewska-Różycka, 2017, s. 15-16]:

- Ekspresja i rozumienie języka oceniane według standaryzowanych testów mieszczą się w granicach dwóch odchyleń standardowych, stosownie do wieku dziecka.

- Możliwa do potwierdzenia niemożność mówienia w specyficznych sytuacjach, w których mówienie jest od dziecka oczekiwane, pomimo mówienia w innych sytuacjach.

- Czas trwania wybiórczego mutyzmu przekracza cztery tygodnie (z wyłączeniem pierwszego miesiąca pobytu w nowej placówce).

- Nie występują żadne z całościowych zaburzeń rozwoju (F84-), specyficzne zaburzenia rozwoju mowy i języka (F80-), schizofrenia (F20-), przemijający mutyzm związany z lękiem przed separacją u małych dzieci (F93.0).

- Zaburzenia nie wyjaśnia brak znajomości języka mówionego wymaganego w sytuacjach społecznych, w których występuje niemożność mówienia.

Kryteria diagnostyczne mutyzmu wybiórczego (F94.0) w klasyfikacji DSM-V (2013) pokrywają się z kryteriami z ICD-10 i dodatkowo podkreślają, że milczenie dziecka jest przeszkodą w osiąganiu postępów w sferze edukacyjnej lub zawodowej, a także zaburza komunikację społeczną [za Ołdakowska-Żyłka, Grąbczewska-Różycka, 2017, s. 16].

W opisie samej kategorii diagnostycznej „mutyzm wybiórczy” zauważa się, że „u wyraźnej mniejszości dzieci wywiad wskazuje na opóźnienia rozwoju mowy, albo na trudności w artykulacji” [Klasyfikacja zaburzeń psychicznych..., 2000]. W żadnej z klasyfikacji nie podkreśla się natomiast znaczenia na przykład deficytów neurorozwojowych czy deficytów przetwarzania słuchowego dla diagnozy MW, a - jak podkreślają Justyna Holka-Pokorska, Agnieszka Piróg-Balcerzak i Jarema Marek [2018, s. 340] - u osób z mutyzmem wybiórczym często obserwuje się współwystępujące deficyty rozwojowe i/lub dysfunkcje z zakresu przetwarzania słuchowego.

W literaturze przedmiotu zwraca się uwagę na wskazania i przeciwwskazania w odniesieniu do diagnozy MW. I tak wskazania w kierunku diagnozy MW są następujące [Johnson, Wintgens, 2018, s. 78]:

- dziecko wykazuje spójny wzorzec mówienia i niemówienia wobec określonych osób w określonych okolicznościach;

- dziecko nie mówi nawet wtedy, gdy leży to w jego interesie (por. np. potrzeba fizjologiczna, złamana ręka);

- dziecko opisuje uczucie „znieruchomienia” jako niemożność wydania głosu lub więźnięcie głosu w gardle. 
Jeśli chodzi o przeciwwskazania, to wymienia się tu między innymi [Johnson, Wintgens, 2018, s. 79-80] następujące:

- dziecko wykazuje takie same ograniczenia w mowie we wszystkich miejscach i sytuacjach;

- dziecko wykazuje niespójne wzorce zachowania związane z mową w identycznych okolicznościach (np. w pewne dni mówi do nauczycielki, w inne tego nie robi);

- dziecko nie mówi bez względu na okoliczności, z wyjątkiem mutyzmu progresywnego;

- nastąpiło nagłe ustanie lub ograniczenie mowy w określonych okolicznościach (np. dziecko jest dręczone, krytykowane lub widziało, jak kolega dostał reprymendę za odzywanie się);

- dziecko bardzo wstydzi się trudności z mówieniem lub odmiennego akcentu, obawia się przedrzeźniania, poprawiania, trudności w wyjaśnieniu innym, o co mu chodzi.

Warto pamiętać o tym, że [Johnson, Wintgens, 2018, s. 80]:

- nie należy mylić mutyzmu wybiórczego z mutyzmem pourazowym (traumatic mutism);

- mutyzm wybiórczy nie ma związku z psychogenną utratą głosu (psychogenic voice disorder);

- niektóre dzieci lepiej określić jako „niechętnie mówiące” (reluctant speakers).

Poza wymienionymi wyżej objawami świadczącymi o mutyzmie wybiórczym wyróżnia się szereg objawów, które nie wskazują na wystąpienie tego zaburzenia. Należą do nich następujące przypadki/sytuacje [Skoczek, 2015, s. 90; Bystrzanowska, 2017, s. 57]:

- dziecko nie rozmawia nigdzie, gdyż u dziecka nie rozwinęła się mowa;

- dziecko ma stwierdzoną niepełnosprawność intelektualną, chorobę genetyczną bądź inną chorobę przewlekłą, w której przebiegu występują bądź mogą występować trudności z komunikacją werbalną; można tu wymienić:

- trudności w werbalnym komunikowaniu się z otoczeniem wynikające z niedosłuchu, głuchoty lub głuchoniemoty;

- zaburzenia wynikające z dysfunkcji OUN, afazji (zwłaszcza motorycznej/ekspresywnej);

- trudności wynikające z zaburzeń ze spektrum autyzmu (dziecko nie mówi, nie nawiązuje kontaktu werbalnego, izoluje się - istnieje wiele podobieństw do zachowań mutystycznych, stąd konieczność weryfikacji symptomów);

- trudności związane z chorobą psychiatryczną, na przykład schizofrenią katatoniczną;

- utrata mowy lub jej redukcja jest nagła (należy poszukiwać możliwych czynników wywołujących, np. dokuczanie w szkole, zastraszanie, silny stres na skutek przeżytej traumy); 
- u dziecka można zdiagnozować zespół stresu pourazowego lub mutyzm traumatyczny;

- nieznajomość języka wynika z faktu, że rodzice dziecka są imigrantami;

- dziecko ma stwierdzoną logofobię, lęk separacyjny, nieśmiałość.

Badanie diagnostyczne powinno służyć rozpoznaniu wzorca, głębokości i skutków mutyzmu wybiórczego, sprawdzeniu, czy nie występują inne poważne lub powiązane $\mathrm{z}$ mutyzmem problemy, ustaleniu, $\mathrm{w}$ jakim stopniu osoby zaangażowane rozumieją mutyzm i czy właściwie z nim postępują oraz zebraniu pełnych informacji na temat rozwoju, zainteresowań i przyjaźni dziecka, tak aby móc podjąć skuteczną interwencję. Każde badanie diagnostyczne powinno objąć cztery kluczowe obszary [Johnson, Wintgens, 2018, s. 85]:

- wzorzec mutyzmu wybiórczego (nawyki związane z mową);

- sposoby, w jakie dom i szkoła postępują z mutyzmem (by wykryć istotne czynniki podtrzymujące);

- mowę, język i profil poznawczy dziecka;

- profil emocjonalny i społeczny (włączając w to wszelkie inne czynniki, które mogą podkopywać pewność siebie dziecka).

W ramach badania diagnostycznego należy stwierdzić, czy mamy do czynienia $\mathrm{z}$ „,czystym” mutyzmem wybiórczym, czy też z mutyzmem wybiórczym i zaburzeniem mowy lub języka albo nauką nowego języka lub też z mutyzmem wybiórczym i innym rozpoznaniem (zespół Aspergera, fobia społeczna, problemy natury medycznej, środowiskowej lub emocjonalnej, mutyzm progresywny) [Johnson, Wintgens, 2018, s. 78].

Mówiąc o diagnozie mutyzmu wybiórczego, zwraca się uwagę na trafność, kompleksowość oraz multimodalne podejście. Najważniejsze dla dziecka/ucznia jest jak najszybsze zdiagnozowanie problemu i podjęcie odpowiednich działań terapeutycznych. Zebranie jak największej ilości informacji na temat funkcjonowania dziecka w bliższej i dalszej rodzinie, środowisku rówieśniczym, przedszkolu, szkole, wśród znajomych jest kwestią najważniejszą w procesie diagnostycznym i to od samego jego początku. By rozpocząć terapię dziecka/ucznia z mutyzmem wybiórczym, nie trzeba czekać na specjalistyczną diagnozę. Działania terapeutyczne można wdrożyć już u dziecka/ucznia, u którego podejrzewamy zaburzenia niemówienia o charakterze lękowym.

Mając na uwadze powyższe, proponuję wyróżnić cztery etapy procesu diagnozowania:

- diagnozę wstępną;

- diagnozę wstępną pogłębioną/rozszerzoną;

- diagnozę wielospecjalistyczną I stopnia;

- diagnozę wielospecjalistyczną II stopnia. 


\section{Diagnoza wstępna}

Bardzo często nauczyciel/wychowawca (w przedszkolu, szkole) jako pierwszy zauważa problem, z jakim zmaga się dziecko z mutyzmem wybiórczym. Taka osoba może dokonać wstępnego rozeznania (poprzez obserwację) w problemach dziecka wskazujących na MW. Powinna zwrócić uwagę na to, czy dziecko/uczeń [Ołdakowska-Żyłka, Grąbczewska-Różycka, 2017, s. 72]:

- komunikuje się werbalnie z rówieśnikami (tylko z jednym czy z kilkoma, czy ze wszystkimi?);

- komunikuje się werbalnie z pracownikami placówki;

- komunikuje swoje trudności i problemy;

- bierze udział w zabawach grupowych (zarówno wymagających porozumiewania się werbalnego, jak i niewymagających);

- je w towarzystwie innych osób;

- zaspokaja potrzeby fizjologiczne w przedszkolu/szkole;

- nie ma nadwrażliwości słuchowej, dotykowej;

- czy wyraz twarzy i postawa nie wskazują na wzmożone napięcie mięśniowe (np. zaciskanie warg, przygryzanie warg, sztywność ciała itp.);

- nie ma problemu z przebieraniem się przed i po zajęciach $\mathrm{z}$ WF-u.

\section{Diagnoza wstępna pogłębiona/rozszerzona}

Takiej diagnozy może dokonać specjalista (np. logopeda) z kompetencjami w diagnozowaniu MW/odpowiednio przygotowany w zakresie wiedzy i umiejętności z diagnozowania MW. Narzędziami diagnostycznymi na tym etapie mogą być:

- kwestionariusz wywiadu z rodzicami dziecka z podejrzeniem mutyzmu wybiórczego;

- kwestionariusz wywiadu z nauczycielem/wychowawcą dziecka z podejrzeniem mutyzmu wybiórczego.

W celach monitorowania postępów można te kwestionariusze odpytywać w odstępach miesięcznych, dwumiesięcznych, półrocznych itp.

O co pytać rodziców w wywiadzie [por. Ołdakowska-Żyłka, Małachowska, 2015]?

- Czy było w rodzinie poronienie, czy rodzice długo starali się o dziecko?

- Czy ktoś w rodzinie był nieśmiały, czy miał problemy psychiczne, depresję?

- Czy dziecko ma kontakt emocjonalny z rodzicami, rodzeństwem? (o funkcjonowanie dziecka w rodzinie).

- Jak dziecko komunikuje się z najbliższymi członkami rodziny, dalszą rodziną, znajomymi rodziny (z kim nie rozmawia, $\mathrm{z}$ kim rozmawia)?

- Jak komunikuje się z rodziną $\mathrm{w}$ obecności innych?

- Czy rozmawia przez telefon $\mathrm{z}$ rodziną, $\mathrm{z}$ obcymi? 
- Jak komunikuje się ze znajomymi rówieśnikami, np. na podwórku?

- Jak komunikuje się zosobami obcymi w miejscach publicznych, np. ze sprzedawcą?

- Jakniemówienie wpływa na sytuację dziecka w przedszkolu/szkole, na jego życie?

- Czy niemówienie dziecka przeszkadza rodzicom?

- Czy dziecko ma swoje miejsce w domu? Czy bawi się w domu, czy naśladuje rodziców?

- Jak rodzice funkcjonują społecznie, jakie są ich relacje z rodzicami, sąsiadami, znajomymi?

- Czy dziecko w nowych sytuacjach obgryza paznokcie, moczy się, jest agresywne?

- Czy dziecko unika wyjścia do szkoły?

- Czy dziecko ma zaburzenia integracji sensorycznej (czy zaburzony jest zmysł dotyku, czucia)?

- Czy dziecko ma problemy z jedzeniem, piciem, korzystaniem z łazienki w przedszkolu/szkole, czy zgłasza problemy fizjologiczne? Czy ma często zapalenie pęcherza moczowego?

- Czy dziecko ma powolne reakcje?

- Czy ma wahania nastroju, zwłaszcza w domu - hałaśliwość, wybuchy złości i płaczu?

- Czy dziecko jest perfekcjonistą?

- Czy samodzielnie się ubiera, zakłada buty?

- Czy samo śpi, samo je?

- Czy kupi sobie samo, np. lody, słodycze?

- O separację dziecka z rodzicem, np. jak zachowywało się dziecko, gdy poszło do przedszkola i musiało rozstać się z mamą (dzieci te nie ujawniają emocji).

- Jak często zezwalano dziecku radzić sobie z ludźmi i zadaniami bez udziału rodziców?

- Jak często zezwalano mu na kontaktowanie się z innymi dziećmi?

- W jakim zakresie zezwalano mu na samodzielne podejmowanie decyzji?

- Czy robiono lub decydowano za nie zbyt często?

$\mathrm{W}$ aspekcie diagnozy różnicowej podczas wywiadu z rodzicami należy zapytać o choroby laryngologiczne, psychiatryczne, przeżycia w ostatnim czasie, o to, czy dziecko nie doświadczyło ostatnio jakiejś poważnej sytuacji stresowej (np. wypadek komunikacyjny, śmierć bliskiej osoby), czy nie było świadkiem jakiegoś tragicznego zdarzenia itp. Pytamy o objawy lęku separacyjnego bądź występowanie objawów ze spektrum autyzmu. Sprawdzamy lub pytamy o reakcje dziecka na dźwięki z otoczenia, rozumienie poleceń kierowanych do dziecka, do całej grupy. W czasie badania logopedycznego lub słuchania nagrań wypowiedzi dziecka należy zwrócić uwagę, czy nie występują wady wymowy, objawy jąkania, afazji [Bystrzanowska, 2017, s. 57].

O co pytać nauczyciela/wychowawcę w wywiadzie [por. Ołdakowska-Żyłka, Malachowska, 2015]? 
- Czy dziecko/uczeń na zajęciach mówi chóralnie wiersze, śpiewa (gdy nauczyciel patrzy i gdy nie patrzy na nie/niego)?

- Jak dziecko/uczeń komunikuje się z rówieśnikami (czy rozmawia z jednym, czy z kilkoma)?

- Czy odmowa mówienia trwa ponad miesiąc i nie ograniczała się tylko do pierwszego miesiąca uczęszczania do przedszkola/szkoły?

- Czy dziecko/uczeń aktywnie uczestniczy w zajęciach (np. tych niewymagających mówienia)?

- Czy dziecko/uczeń udziela się w grupie/klasie niewerbalnie (np. wskazuje palcem, gestykuluje)?

- Czy dziecko/uczeń rozmawia z którymś z nauczycieli, pracowników placówki?

- Czy dziecko/uczeń odpowiada na pytania nauczyciela, czy zadaje nauczycielowi pytania?

- Czy dziecko/uczeń rozmawia z rodzicami w obecności nauczyciela?

- Czy dziecko/uczeń rozmawia z rówieśnikami poza szkołą, np. na wycieczce szkolnej?

- Czy dziecko/uczeń zjada posiłki w szkole, korzysta z toalety?

- Czy odmowa mówienia ma znaczny wpływ na edukacyjne osiągnięcia lub społeczną komunikację?

Istnieją także gotowe kwestionariusze diagnostyczne autorstwa Anny Skoczek [2015], Marii Bystrzanowskiej [2017], Barbary Ołdakowskiej-Żyłki i Katarzyny Grąbczewskiej-Różyckiej [2017] oraz Maggie Johnson i Alison Wintgens [2018].

\section{Diagnoza wielospecjalistyczna I stopnia}

Czasem istnieje konieczność przeprowadzenia pełnej diagnostyki, łącznie z dodatkowymi badaniami wykluczającymi lub potwierdzającymi wstępną diagnozę [Bystrzanowska, 2017, s. 49].

Wskazania do formalnej diagnostyki dziecka/ucznia, u którego podejrzewamy MW (potwierdzonej przez specjalistów w poradni psychologiczno-pedagogicznej i lekarza psychiatrę bądź neurologa) [Bystrzanowska, 2017, s. 50] są następujące:

- objawy nie dają jednoznacznego obrazu zaburzenia, gdyż u dziecka/ucznia współwystępują inne zaburzenia;

- mimo wdrożonych oddziaływań nieformalnych w przedszkolu/szkole u dziecka/ucznia nie ma żadnych efektów terapeutycznych;

- objawy sugerują ciężką postać MW;

- w przedszkolu/szkole z różnych względów nie ma możliwości diagnostycznych i terapeutycznych;

- istnieje podejrzenie, że trudności w komunikowaniu się z otoczeniem mogą wynikać z innych przyczyn zdrowotnych lub życiowych; 
- terapia i pomoc dziecku/uczniowi w przedszkolu/szkole są możliwe dopiero po wydaniu przez poradnię psychologiczno-pedagogiczną stosownych dokumentów, na przykład opinii o potrzebie wczesnego wspomagania rozwoju, $z$ adekwatnymi dla danego dziecka/ucznia zaleceniami, bądź orzeczenia.

Ustaleniem diagnozy mutyzmu zajmuje się zespół specjalistów, na przykład w poradni psychologiczno-pedagogicznej, w skład którego wchodzą, w zależności od obrazu klinicznego dziecka:

- psycholog - ocenia zdolności poznawcze i dojrzałość emocjonalną;

- pedagog - ocenia umiejętności dydaktyczne dziecka;

- (neuro)logopeda - ocenia artykulację i umiejętności komunikacyjne;

- psychiatra - stawia diagnozę mutyzmu wybiórczego.

W przypadku zaburzenia komunikacji werbalnej, a takim zaburzeniem jest mutyzm wybiórczy, diagnoza ma szeroki zakres, jest kilkuelementowa. Najważniejszym elementem jest przeprowadzenie diagnozy wykluczającej.

Trudności diagnostyczne nie sprowadzają się jedynie do wykluczenia zaburzeń z podobnymi objawami w aspekcie dotyczącym komunikacji werbalnej. Problem osoby diagnozującej to również rozpoznanie MW wówczas, kiedy sprzężony jest z zaburzeniami współwystępującymi, przykładowo: z uogólnionymi zaburzeniami lękowymi, fobią społeczną, zespołem Aspergera [Skoczek, 2015, s. 91-92].

\section{Diagnoza wielospecjalistyczna II stopnia}

Niestety, nie zawsze na podstawie informacji, które dotychczas posiadamy, możemy wykluczyć inne przyczyny niemówienia. Czasem konieczne jest przeprowadzenie konsultacji specjalistycznych i skierowanie dziecka na dodatkowe badania diagnostyczne [Bystrzanowska, 2017, s. 57], takie jak: badania audiologiczne, neurologiczne czy pogłębione badania psychiatryczne. Mając ich wyniki, jesteśmy w stanie wskazać bądź wykluczyć przyczyny niemówienia.

Na zakończenie warto raz jeszcze zadać pytania: „Czy zawsze konieczne jest postawienie formalnej, pełnej diagnozy dziecka/ucznia?”, „Czy z rozpoczęciem terapii należy czekać na pełną, formalną diagnozę?".

Otóż nie zawsze konieczne jest postawienie formalnej, pełnej diagnozy dziecku, u którego na początku kariery przedszkolnej/szkolnej wystąpiły objawy MW, nawet jeżeli spełnione są wszystkie kryteria diagnostyczne tego zaburzenia lękowego zamieszczone w ICD-10. W przypadku gdy nie stwierdza się dodatkowych objawów, które świadczyłyby o możliwości wystąpienia innych zaburzeń, nie czekając na formalną diagnozę, można w przedszkolu/szkole wdrożyć pewne oddziaływania naprawcze. Często bywa tak, że dzieci bez diagnozy psychiatrycznej, poddane interwencji terapeutycznej, zaczynają komunikować się werbalnie z otoczeniem. 


\section{Podsumowanie}

Mutyzm wybiórczy jest zaburzeniem o podłożu lękowym, z którego się nie wyrasta i które wymaga specjalistycznej terapii. Najlepsze i najszybsze rezultaty przynosi rozpoczęty jak najwcześniej proces terapeutyczny. Dlatego tak ważne jest szybkie zdiagnozowanie u dziecka mutyzmu wybiórczego.

Diagnoza mutyzmu wybiórczego nie jest zadaniem łatwym, dlatego, zdaniem Maggie Jonson i Alice Wintgens [2018, s. 84], powinna przeprowadzić ją osoba, która:

- ma wiedzę na temat mutyzmu wybiórczego i zalicza go do kategorii zaburzeń lękowych;

- nie myli mutyzmu z nieśmiałością, autyzmem, depresją czy problemami behawioralnymi, takimi jak potrzeba kontrolowania innych ludzi;

- bada alternatywne wyjaśnienia niemożności mówienia i, jeśli zachodzi taka potrzeba, kieruje dziecko do specjalistów z innych dziedzin;

- potrafi rozpoznać czynniki przyczyniające się do mutyzmu i podtrzymujące go, szukając potwierdzenia dla diagnozy, a także wskazać punkt wyjścia odpowiedniej interwencji.

W przypadku mutyzmu wybiórczego diagnoza ma szeroki zakres i może być kilkuetapowa. Zaproponowany przeze mnie czteroetapowy proces diagnostyczny (diagnoza wstępna, diagnoza wstępna pogłębiona/rozszerzona, diagnoza wielospecjalistyczna I stopnia, diagnoza wielospecjalistyczna II stopnia) wymaga dobrze przygotowanej specjalistycznej kadry. Na etapie diagnozy wstępnej może być to wychowawca/nauczyciel dziecka, w drugim etapie (neuro)logopeda. Dwa ostatnie etapy (tzw. wielospecjalistyczne) to etapy, w których diagnozy dokonuje zespół specjalistów, na przykład w poradni psychologiczno-pedagogicznej. W skład takiego zespołu wchodzą, w zależności od obrazu klinicznego dziecka: psycholog (ocenia zdolności poznawcze i dojrzałość emocjonalną), pedagog (ocenia umiejętności dydaktyczne dziecka), (neuro)logopeda (ocenia artykulację i umiejętności komunikacyjne) oraz psychiatra (stawia diagnozę mutyzmu wybiórczego). Czasem konieczne jest przeprowadzenie konsultacji specjalistycznych i skierowanie dziecka na dodatkowe badania diagnostyczne, takie jak: badania audiologiczne, badania neurologiczne czy pogłębione badania psychiatryczne.

Badania na pierwszym i drugim etapie, mające najczęściej charakter badań skriningowych, służą do postawienia diagnozy wstępnej, po której terapia dziecka może być już rozpoczęta. 
Literatura

Andrzejewska M., 2015, Materiały ze szkolenia: Mutyzm selektywny-pomoc psychologiczna dla dziecka i jego rodziny, I-II stopień, Łódź.

Bogdanowicz M., 1985, Psychologia kliniczna dziecka $w$ wieku przedszkolnym, Warszawa: Wydawnictwa Szkolne i Pedagogiczne.

Bystrzanowska M., 2017, Mutyzm wybiórczy. Poradnik dla rodziców, nauczycieli i specjalistów, Kraków: Oficyna Wydawnicza Impuls.

Bystrzanowska M., Bystrzanowska E. (red.), 2019, Mutyzm wybiórczy. Skuteczne metody terapii, Kraków: Oficyna Wydawnicza Impuls.

Holka-Pokorska J., Piróg-Balcerzak A., Jarema M., 2018, Kontrowersje wokół diagnozy mutyzmu wybiórczego - krytyczna analiza trzech przypadków w świetle współczesnych badań oraz kryteriów diagnostycznych, „Psychologia Polska”, nr 52(2), s. 323-343.

Janik I., 2012, Mutyzm dziecięcy, [w:] J. Skibska, D. Larysz (red. nauk.), Neurologopedia $w$ teorii i praktyce. Wybrane zagadnienia diagnozy i terapii dziecka, Bielsko-Biała: Wydawnictwo Naukowe Akademii Techniczno-Humanistycznej, s. 79-94.

Johnson M., Wintgens A., 2018, Mutyzm wybiórczy. Kompendium wiedzy, Gdańsk: Wydawnictwo Harmonia.

Klasyfikacja zaburzeń psychicznych i zaburzeń zachowania w ICD-10. Opisy kliniczne i wskazówki diagnostyczne, 2000, Kraków-Warszawa: Uniwersyteckie Wydawnictwo Medyczne „Vesalius”, Instytut Psychiatrii i Neurologii.

Ołdakowska-Żyłka B., 2015, Mutyzm wybiórczy w Polsce i na świecie, „Forum Logopedy”, nr 9, s. $61-64$.

Ołdakowska-Żyłka B., Grąbczewska-Różycka K., 2017, Mutyzm wybiórczy. Strategie pomocy dziecku i rodzinie, Warszawa: Wydawnictwo Difin.

Ołdakowska-Żyłka B., Małachowska E., 2015, Materiały ze szkolenia: Pomoc psychologiczna dziecku z mutyzmem wybiórczym i jego rodzinie, Łódź.

Radomska A., Jankowska A., 2000, W fortecy milczenia, „Charaktery”, nr 4, s. 20-21.

Skoczek A., 2015, Mutyzm. Zagadnienia teorii i praktyki, Kraków: Akademia Ignatianum, Wydawnictwo WAM.

Urbaniuk J., 2008, Dziecko z mutyzmem wybiórczym, [w:] B. Cytowska, B. Winczura, A. Stawarski (red.), Dzieci chore, niepetnosprawne i $z$ utrudnieniami w rozwoju, Kraków: Oficyna Wydawnicza Impuls, s. 455-470.

Warchał A., Warchał M., 2012, Współwystępowanie mutyzmu wybiórczego w zaburzeniach nerwicowych, [w:] J. Skibska, D. Larysz (red. nauk.), Neurologopedia w teorii i praktyce. Wybrane zagadnienia diagnozy i terapii dziecka, Bielsko-Biała: Wydawnictwo Naukowe Akademii Techniczno-Humanistycznej, s. 95-106. 


\section{Streszczenie}

Nowe postrzeganie mutyzmu wybiórczego jako zaburzenia na tle lękowym pozwala specjalistom na wczesną jego diagnozę i jak najszybsze podjęcie działań terapeutycznych. Diagnoza mutyzmu wybiórczego nie jest zadaniem łatwym, a w proces diagnozowania może być zaangażowanych wielu specjalistów. Badanie diagnostyczne powinno służyć: rozpoznaniu wzorca, głębokości i skutków mutyzmu wybiórczego, sprawdzeniu, czy nie występują inne poważne lub powiązane z mutyzmem problemy, ustaleniu, w jakim stopniu osoby zaangażowane rozumieją mutyzm i czy właściwie z nim postępują oraz zebraniu pełnych informacji na temat rozwoju, zainteresowań i przyjaźni dziecka, tak aby móc podjąć skuteczną interwencję. Celem artykułu jest omówienie mutyzmu wybiórczego i diagnozy jako procesu oraz przedstawienie własnej propozycji klasyfikacji jego etapów.

\section{Abstract}

The new perception of selective mutism as an anxiety disorder enables specialists to diagnose it early and take therapeutic measures as soon as possible. It is not an easy task to diagnose selective mutism and that process can engage many specialists. A diagnostic test should identify a pattern, depth and effects of selective mutism and also check whether there occur other serious problems related to this disorder. The test should help to determine how well do the people dealing with SM understand it and whether they apply the correct treatment. It should also help to collect full information on development, interests and friendships of a child to be able to help him efficiently. The aim of the article is to present the selective mutism and is to present the diagnosis as the process and to offer some suggestions how to classify the stages of this process. 